\title{
DECOMPOSITION OF FINANCIAL CAPACITY OF UKRAINIAN HOUSEHOLDS IN THE CONDITIONS OF CHANGING ECONOMIC ENVIRONMENT: REGIONAL SECTION*
}

\author{
Olha Mulska', Taras Kloba²
}

\begin{abstract}
Challenges of economic instability update the study of their impact on the architecture of economic and consumer behavior of Ukrainian households, which determines their financial capacity. The purpose of the article is to carry out a comparative analysis of the financial capacity of Ukrainian households at the regional level and to identify applied features of consumer behavior in the economic crisis. The object is the financial capacity of Ukrainian households in terms of regions. The subject of research: analysis of different models of behavior of households in Ukraine (consumer, investment, and savings), which will determine the financial orientation of families by region. Research methodology. The methodological tools for assessing the economic behavior of households with the definition of its leading models - consumer, investment, savings, the correlation of which allows to determine the decomposition of the financial capacity of the territory (country, region, community). The methodological approach has been tested, which can serve as a basis for structuring management tasks in terms of strengthening the investment activities of households, ensuring the optimal structure of consumer spending to form the territory's resilience to financial shocks. An analysis of the economic behavior of households, based on the assessment of reflections - consumer, investment, and savings - as a result of the subject's understanding of its financial capacity, expressed in terms of costs and financial resources. The study results can help reflect the state of providing the entity with financial resources. These other tangible and intangible assets may be capitalized shortly and reoriented from consumption and savings to investment purposes of financial capacity of households in Ukraine. Improving the financial condition of households is closely linked to the resumption of economic activity of enterprises, as families are one of the most critical economic categories. An essential tool is an effective regional policy to level interregional disparities and effective long-term strategies for household financial behavior. Particular attention should be paid to financial planning, which is a prerequisite for effective management and control over the financial condition of households, which will balance the structure of income and expenditure, avoid unplanned expenses, rational use of available resources. When it comes to making financial decisions, they are always sensible, planned based on the real needs of household members or the adequacy of financial resources. Prospects for further research will be problem-solving, which is possible only at the state level and requires effective management decisions and the identification of different macroeconomic trends in the national economy.
\end{abstract}

Key words: economic growth, financial capacity, economic behavior, territory, household, conditions of variability. JEL Classification: 013, 018, D19

\section{Introduction}

The issue of consumer research has a multifaceted nature. On the one hand, modern society is evolving as a consumer. The ideas of thrift, conservation of environmental resources with the promotion of long-

\footnotetext{
Corresponding author:

${ }^{1}$ State Institution "M.I. Dolishniy Institute of Regional Research of the National Academy of Sciences of Ukraine", Ukraine.

E-mail: oliochka.mulska@gmail.com

ORCID: https://orcid.org/0000-0002-1666-3971

${ }^{2}$ State Institution "M.I. Dolishniy Institute of Regional Research of the National Academy of Sciences of Ukraine", Ukraine.

E-mail: taras@klioba.com

ORCID: https://orcid.org/0000-0002-3354-3648
}

term consumption are increasingly promoted. On the other hand, the priorities of consumerism remain with the growing rights of consumers, particularly regarding access to quality products and in sufficient quantities. For societies that are developing or in

\footnotetext{
*The study was performed under the grant 2020.02/0215, "Financial determinants of economic growth of regions and territorial communities based on behavioral economics," with the support of NFDU.
} 
a transformational environment, to which Ukraine belongs, the study of consumption and cost structure has a rather acute social character. However, it is intertwined with the structural shortcomings of the economy and the contradictions of innovative development.

The issue of studying the financial capacity of households is relevant in both theoretical and applied sense. For Ukraine, it acquires socially significant features given the need to improve the welfare of the population, improve other quality indicators of its life, and the formation of regional development programs, the concept of the financial well-being of communities and territories.

In the scientific discourse, there are numerous studies of consumer behavior, and the financial capacity of households, in terms of analyzing the structure of expenditures in the regions of Ukraine to identify the importance of consumer, investment, and savings activities. The results of the study develop ideas about the content of behavior in economic theory (Harasymiv, 2016; Teremtsova, 2010), the specifics of consumer behavior (Vasylkevych, 2011; Derkach, 2020; Kuzmuk, 2015; Pohorila, 2006). Identifying the features of the analysis of consumer behavior at the household level is carried out taking into account the regulations (Stankevych, 2008) and the results of research (Melykh, 2020; Stankevych, 2008; Cherenko, 2019; Bil, 2021; Mulska, 2021).

As a rule, consumer behavior is considered through the prism of the influence of marketing tools at the individual level. However, consumer behavior needs research with a more fundamental vision - forming a behavioral economy, ensuring the welfare of the population, and the impact on sustainable economic growth. Therefore this publication develops a methodology for researching consumer behavior in a more complex context.

\section{Materials and methods of research}

In the course of this study, various scientific methods and approaches were used, in particular, a systematic approach to ensure the analysis of the theoretical basis of the behavioral economy of households and the study of the processes of formation of consumer behavior. The dialectical method in the analysis of the current state and prospects of development of the behavioral economy of households at the level of regions of Ukraine; methods of economic analysis in the study of the characteristics of consumer, investment and savings activity of homes, in identifying interregional differences and relationships; methods of scientific abstraction, induction, and deduction in the formulation of recommendations for the regulation of consumer behavior of households, it's theoretical modeling in modern conditions.
The information base was primary sources, monographs of domestic and foreign authors, scientific publications in specialized publications, statistical and information bulletins of government agencies.

\section{Results and discussion}

The consumer behavior of households in Ukraine is constantly changing under economic shocks, political instability, growing social vulnerability, and, consequently, societal tensions. Moreover, the lack of sustainable economic growth over time leads to increased social inequality and deepening poverty, reduces the ability of households to save, and even more investment, their resources, causes the spread of migration among the population, especially young people, and generally threatens the quality of life, in the country.

According to a sample survey of the socio-economic situation of households, the absolute poverty rate in Ukraine in 2019 was nominally 1.1\% (in 2016 $3.3 \%)$, which indicates a slight reduction in the share of households with per capita equivalent total income, lower than the statutory subsistence level. At the same time, the de-facto poverty rate is much higher when comparing incomes with the estimated subsistence level: in particular, in 2016 and 2019, the poverty rate reached $48.2 \%$ and $23.3 \%$ of households, respectively (Derzhavna sluzhba statystyky Ukrainy. Sotsialno-ekonomichne stanovyshche, 2019). Thus, despite reducing absolute poverty in Ukraine, its level remains high and varies significantly by region. Thus, considering the depth of income poverty, the worst situations traditionally include Rivne, Kherson, Luhansk, Zhytomyr, and Kyiv (excluding the city of Kyiv) oblasts, which affect the patterns of consumer behavior in these regions. (Cherenko, 2019). In general, the regional specificity of the formation of financial capacity of households is determined by socioeconomic determinants of the development of a particular region, the activity of territorial communities of which it consists, settlement structure, and other objective and subjective environmental factors.

The analysis of the dynamics of consumer aggregate household expenditures for 2009-2019 (Table 1) shows a relatively uniform growth of the indicator by region during the study period, in particular, 3.1-4.3 times compared to 2009 (the average value in Ukraine in 2009 and 2019 amounted to 2417.1 and 8826.3 UAH per month, respectively). However, if we compare the currency equivalent of household consumption expenditures (in EUR), the dynamics are less pronounced (an increase of 1.2-1.6 times) due to the depreciation of the national currency. Thus, the increase in consumption and household income is evidence-primarily of the impact of inflation in 
the country against the background of overall low purchasing power.

At the same time, the share of cash income accounted for by total consumer expenditures of households in Ukraine in 2019 was $79.2 \%$, which is 11.3 percentage points. less than in 2009 (90.5\%) (Figure 1).

Therefore, nominally households have become more solvent because they consume less of their cash income and conserve resources to finance non-consumer needs. However, in reality, these changes did not significantly affect the population's living standards, which remains one of the lowest among European countries. Nevertheless, the noticeable social stratification in the regional aspect attracts attention.

Thus, according to the above indicator, the least financially viable in ensuring their consumer spending (according to 2019) are households of Mykolaiv (88.8\%), Chernihiv (88.7\%), and Zaporizhzhia $(86.9 \%)$ regions, while the most secured - families of Odesa region (67.0\%). Almost $70-90 \%$ of cash income goes to consumption, thus limiting households' savings and investment activity. Thus is direct evidence of the monetary poverty of the population. In previous years, this figure in some regions (Volyn, Ivano-Frankivsk, Rivne, Ternopil, Cherkasy, etc.) exceeded $100 \%$, i.e., the income received did not cover the consumer needs of households, to meet which, probably, used savings, borrowed capital, and other sources. Among the reasons for this situation are the higher percentage of the rural population in these areas and the larger share of the people employed in agriculture, forestry, fishing, and hunting. And this, in turn, affects the structure of the comprehensive resources of households. Thus, the share of cash income in more urbanized regions is higher compared to areas where households make extensive use of non-monetary sources, in particular in the form of products obtained from personal farms and self-procurement. Thus, the importance of the socio-demographic characteristics of households in shaping their consumer behavior.

Table 1

Dynamics of total consumer expenditures of households by regions of Ukraine (on average per month per household, UAH), 2009-2019

\begin{tabular}{|c|c|c|c|c|c|c|c|c|c|c|c|c|}
\hline & 2009 & 2010 & 2011 & 2012 & 2013 & 2014 & 2015 & 2016 & 2017 & 2018 & 2019 & $2019 / 2009$ \\
\hline UKRAINE & 2417,1 & 2765,7 & 3118,3 & 3265,5 & 3444,6 & 3707,4 & 4602,1 & 5331,5 & 6634,1 & 7655,4 & 8826,3 & 3,7 \\
\hline $\begin{array}{l}\text { Autonomous } \\
\text { Republic of Crimea }\end{array}$ & 2342,4 & 2660,2 & 2927,5 & 3090,7 & 3354,4 & $\cdots$ & $\cdots$ & $\cdots$ & $\cdots$ & $\cdots$ & $\cdots$ & $\mathrm{x}$ \\
\hline Vinnytsia & 2281,4 & 2564,9 & 2939,7 & 3119,4 & 3137,9 & 3504,6 & 4704,5 & 5384,2 & 6982,1 & 7547,1 & 8824,3 & 3,9 \\
\hline Volyn & 2219,7 & 2733,5 & 3151,2 & 3286,7 & 3502,8 & 3788,7 & 5065,6 & 5755,4 & 6714,1 & 7850,8 & 8889,4 & 4,0 \\
\hline Dnipropetrovsk & 2310,7 & 2530,1 & 2797,7 & 2947,1 & 3050,4 & 3389,3 & 4082,0 & 4973,7 & 6205,7 & 7707,0 & 8225,2 & 3,6 \\
\hline Donetsk & 2365,1 & 2731,9 & 3124,3 & 3344,7 & 3610,7 & 3333,0 & 3936,7 & 4704,0 & 5799,5 & 6440,7 & 7952,2 & 3,4 \\
\hline Zhytomyr & 2254,1 & 2524,0 & 2663,1 & 2976,7 & 2900,8 & 3342,8 & 4260,7 & 4604,8 & 5930,1 & 6651,1 & 8211,8 & 3,6 \\
\hline Zakarpattia & 2818,8 & 3147,1 & 3701,9 & 3860,9 & 4336,8 & 5000,3 & 6538,4 & 8054,1 & 9167,5 & 10814,3 & 12161,7 & 4,3 \\
\hline Zaporizhzhia & 2196,1 & 2643,0 & 3044,4 & 3340,7 & 3233,8 & 3890,2 & 4522,0 & 4734,6 & 6151,9 & 7747,8 & 8035,8 & 3,7 \\
\hline Ivano-Frankivsk & 2727,7 & 2993,8 & 3184,9 & 3322,1 & 3580,7 & 4012,1 & 5146,8 & 6617,8 & 8411,0 & 8733,9 & 10442,0 & 3,8 \\
\hline Kyiv & 2573,8 & 2762,1 & 2947,9 & 3097,8 & 3434,8 & 3400,5 & 4390,2 & 4867,1 & 5600,0 & 7062,5 & 8429,7 & 3,3 \\
\hline Kirovohrad & 1887,3 & 2067,9 & 2537,1 & 2538,2 & 2835,2 & 3033,4 & 4013,9 & 4655,7 & 5918,9 & 6831,8 & 7740,5 & 4,1 \\
\hline Luhansk & 2199,2 & 2557,3 & 2744,0 & 3137,3 & 3014,5 & 2893,2 & 3319,5 & 4017,7 & 5280,4 & 6158,7 & 6703,7 & 3,1 \\
\hline Lviv & 2646,5 & 2991,2 & 3227,7 & 3474,3 & 3878,8 & 4157,4 & 5369,5 & 6541,7 & 7820,1 & 9252,3 & 11053,6 & 4,2 \\
\hline Mykolaiv & 2546,6 & 2957,8 & 3337,2 & 3597,1 & 3686,0 & 3849,2 & 4263,3 & 5155,6 & 6074,1 & 7642,1 & 8856,0 & 3,5 \\
\hline Odesa & 2327,5 & 2927,9 & 3147,0 & 3185,7 & 3274,4 & 3786,0 & 4680,1 & 5136,3 & 6330,3 & 7164,7 & 8261,7 & 3,6 \\
\hline Poltava & 2023,1 & 2434,5 & 2884,0 & 2864,4 & 3241,8 & 3454,2 & 4312,3 & 4802,8 & 6278,8 & 6694,4 & 7366,9 & 3,6 \\
\hline Rivne & 2431,3 & 2746,1 & 2975,0 & 3044,5 & 3030,5 & 3240,2 & 4193,1 & 4538,6 & 6000,4 & 6489,4 & 8267,0 & 3,4 \\
\hline Sumy & 1868,8 & 2482,1 & 2631,0 & 2563,3 & 2780,4 & 3162,4 & 4187,8 & 4683,6 & 6061,2 & 6845,2 & 7747,7 & 4,2 \\
\hline Ternopil & 2420,4 & 2610,3 & 3026,8 & 3115,7 & 3286,7 & 3651,6 & 5243,2 & 5905,7 & 8553,8 & 8039,6 & 9716,0 & 4,0 \\
\hline Kharkiv & 2347,8 & 2689,7 & 2921,2 & 3095,7 & 3404,6 & 3653,6 & 4380,5 & 4884,0 & 6168,9 & 7106,2 & 7463,5 & 3,2 \\
\hline Kherson & 1938,2 & 2397,9 & 3172,1 & 3175,3 & 3234,4 & 3709,8 & 4060,4 & 5026,6 & 5907,1 & 6363,9 & 7164,8 & 3,7 \\
\hline Khmelnytskyi & 2249,5 & 2518,7 & 2622,4 & 2645,5 & 3008,5 & 3124,9 & 4000,5 & 4978,5 & 6000,0 & 6764,6 & 8229,3 & 3,7 \\
\hline Cherkasy & 2530,5 & 2957,6 & 3307,3 & 3410,7 & 3506,6 & 3584,8 & 4698,3 & 4945,1 & 6141,7 & 6954,5 & 7948,9 & 3,1 \\
\hline Chernivtsi & 2607,4 & 2713,6 & 3057,4 & 3244,4 & 3411,1 & 3984,4 & 4813,8 & 6300,3 & 7317,5 & 8528,4 & 9310,3 & 3,6 \\
\hline Chernihiv & 2171,9 & 2534,9 & 2913,1 & 2874,6 & 3174,6 & 3342,8 & 4573,9 & 4969,6 & 6406,8 & 7998,2 & 8683,9 & 4,0 \\
\hline Kyiv (city) & 3638,8 & 3983,9 & 4905,7 & 4945,3 & 5203,0 & 5088,7 & 6097,3 & 7156,8 & 8787,3 & 10351,6 & 13058,2 & 3,6 \\
\hline Sevastopol (city) & 3131,0 & 3699,1 & 4541,2 & 4591,1 & 3810,8 & $\ldots$ & $\ldots$ & $\ldots$ & $\ldots$ & $\ldots$ & $\ldots$ & $\mathrm{x}$ \\
\hline
\end{tabular}

Note: "..." - no data.

Source: compiled by the authors according to the data (Derzhavna sluzhba statystyky Ukrainy. Vytraty $i$ resursy domohospodarstv Ukrainy, 2009, 2019) 


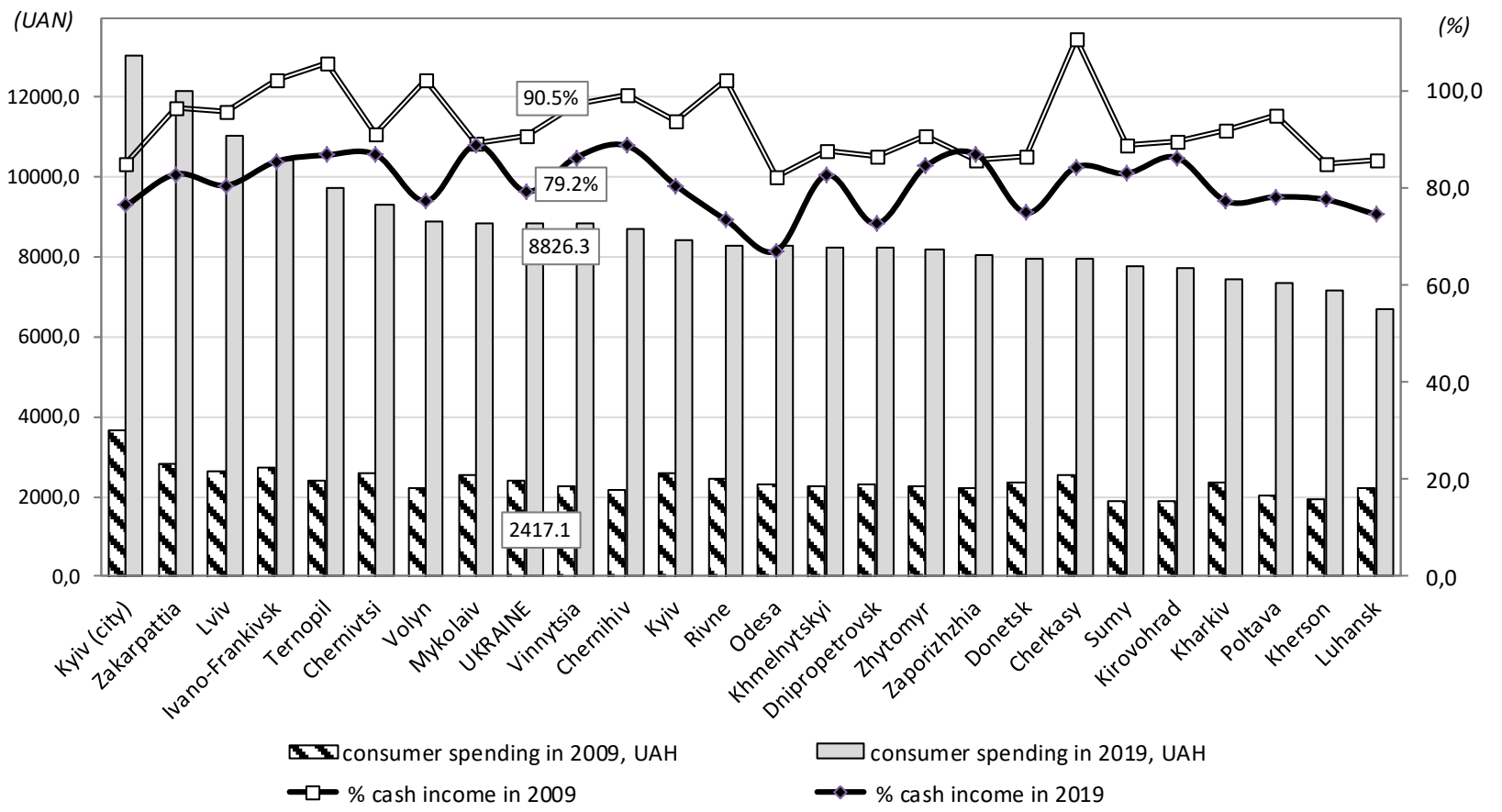

Figure 1. The number of consumer expenditures of households and the share of cash income that provides them, by regions of Ukraine in 2009 and 2019 (on average per month per household)

Source: compiled by the authors according to the data (Derzhavna sluzhba statystyky Ukrainy. Vytraty $i$ resursy domohospodarstv Ukrainy, 2009, 2019)

Almost half of the total household expenditures are spent on food and non-alcoholic beverages (46.6\% in Ukraine as a whole in 2019), while in Volyn, Donetsk, Kyiv (excluding Kyiv), Odesa, and Rivne oblasts this figure exceeded 50,0\%. At the same time, in developed countries, households spend no more than $30 \%$ of their total family income on food (Melykh, 2020).This trend is one of the reasons for Ukrainians' passivity towards savings.

Despite this, positive changes in the consumer capacity of households have taken place. Compared to 2009 , in 2019, the share of homes that spend more than $50 \%$ of total expenditures on food decreased. Moreover, the percentage of households with high risks of social exclusion has significantly reduced (with average per capita equivalent total income per month below the statutory subsistence level) - from $16.2 \%$ in 2009 to $1.1 \%$ in 2019 . This trend indicates a reduction in the depth of poverty.

The investment behavior of households is statistically estimated by the average monthly expenditures on the purchase of shares, real estate (houses, apartments, cottages, garages), construction, major repairs, bank deposits, and the number of contributions to private pension funds. According to official statistics, on average, in 2019, this figure in Ukraine was UAH 445.9 per month per household (4 times more than in 2009) it ranged from UAH 44.0 in the Kyiv region (excluding capital) to $1528.1 \mathrm{UAH}$ in the Chernivtsi region (Table 2).
There is a significant scope of variation due to different income levels and different consumer behavior patterns in the regions. It should be noted that the investment potential of the population in Ukraine is not fully involved due to low financial capacity. And foreign investment in the country's economy has declined due to general socio-economic instability and the military conflict in eastern Ukraine. This situation requires an effective domestic investment policy based on its financial resources.

From 2009 to 2019, the share of investment expenditures in the structure of total spending of households in Ukraine increased from $4.1 \%$ to $4.6 \%$ (Figure 2); in most regions, there were also constructive changes. Of course, these are not significant structural changes, but still, a positive factor is a fact that the population thus increases its financial capacity, forms a resource base for passive income, raises living standards. However, it should be noted that the share of such expenditures in households in developed countries is much higher, so to optimize the structure of total spending, it is necessary to increase investment costs (investments).

Another model of financial behavior of households is saving activity, which is a significant source of economic development and an effective tool to protect capital from economic shocks. In this context, it is necessary to distinguish financially active and financially passive households by region and compare the savings activity of homes with macroeconomic 
Table 2

Investment expenditures * of households by regions of Ukraine (on average per month per household, UAH), 2009-2019

\begin{tabular}{|c|c|c|c|c|c|c|c|c|c|c|c|c|}
\hline & 2009 & 2010 & 2011 & 2012 & 2013 & 2014 & 2015 & 2016 & 2017 & 2018 & 2019 & $2019 / 2009$ \\
\hline UKRAINE & 112,7 & 133,1 & 147,2 & 132,2 & 166,1 & 131,7 & 125,5 & 141,7 & 225,0 & 313,3 & 445,9 & 4,0 \\
\hline $\begin{array}{l}\text { Autonomous } \\
\text { Republic of Crimea }\end{array}$ & 151,7 & 160,9 & 97,5 & 126,9 & 162,6 & $\cdots$ & $\cdots$ & $\cdots$ & $\cdots$ & $\cdots$ & $\cdots$ & $\mathrm{x}$ \\
\hline Vinnytsia & 124,8 & 101,1 & 191,7 & 141,5 & 100,2 & 90,2 & 71,3 & 139,8 & 293,3 & 146,4 & 607,5 & 4,9 \\
\hline Volyn & 41,5 & 78,7 & 65,2 & 81,9 & 115,7 & 143,6 & 83,1 & 76,4 & 188,4 & 292,4 & 361,1 & 8,7 \\
\hline Dnipropetrovsk & 108,1 & 106,3 & 162,8 & 133,1 & 133,4 & 133,8 & 170,2 & 201,1 & 309,8 & 691,3 & 796,7 & 7,4 \\
\hline Donetsk & 107,8 & 136,3 & 99,8 & 90,6 & 97,4 & 63,2 & 29,5 & 32,3 & 246,8 & 203,9 & 131,7 & 1,2 \\
\hline Zhytomyr & 175,4 & 63,4 & 105,2 & 51,8 & 311,0 & 120,7 & 88,1 & 303,1 & 141,3 & 122,5 & 230,9 & 1,3 \\
\hline Zakarpattia & 193,9 & 145,8 & 248,6 & 202,0 & 125,0 & 255,8 & 263,3 & 60,5 & 151,8 & 583,7 & 155,1 & 0,8 \\
\hline Zaporizhzhia & 193,6 & 214,2 & 288,3 & 308,4 & 363,0 & 305,5 & 305,3 & 277,2 & 576,0 & 661,1 & 766,3 & 4,0 \\
\hline Ivano-Frankivsk & 66,6 & 57,8 & 63,8 & 49,9 & 16,8 & 14,6 & 5,6 & 17,7 & 135,7 & 16,7 & 143,6 & 2,2 \\
\hline Kyiv & 127,8 & 94,8 & 193,3 & 91,2 & 153,8 & 98,1 & 44,6 & 1,1 & 68,5 & 16,5 & 44,0 & 0,3 \\
\hline Kirovohrad & 64,7 & 100,1 & 221,6 & 176,5 & 151,1 & 129,2 & 168,3 & 165,4 & 161,1 & 202,6 & 884,9 & 13,7 \\
\hline Luhansk & 152,8 & 147,2 & 166,9 & 221,7 & 212,8 & 290,0 & 307,9 & 230,1 & 380,7 & 691,0 & 680,8 & 4,5 \\
\hline Lviv & 53,5 & 38,5 & 66,6 & 55,0 & 55,6 & 69,3 & 44,8 & 101,6 & 86,0 & 199,2 & 346,2 & 6,5 \\
\hline Mykolaiv & 207,8 & 112,9 & 231,9 & 207,8 & 125,9 & 151,2 & 136,9 & 252,6 & 398,8 & 430,3 & 712,1 & 3,4 \\
\hline Odesa & 96,1 & 197,7 & 65,0 & 58,4 & 132,9 & 94,0 & 60,5 & 72,6 & 84,1 & 41,3 & 249,9 & 2,6 \\
\hline Poltava & 78,1 & 97,1 & 124,1 & 102,2 & 149,3 & 57,1 & 102,1 & 37,4 & 121,2 & 120,6 & 121,2 & 1,6 \\
\hline Rivne & 60,2 & 110,6 & 71,9 & 69,7 & 97,9 & 182,9 & 148,7 & 101,7 & 85,1 & 97,3 & 231,6 & 3,8 \\
\hline Sumy & 142,0 & 154,1 & 229,5 & 127,2 & 123,8 & 172,9 & 370,7 & 389,3 & 264,3 & 258,5 & 287,5 & 2,0 \\
\hline Ternopil & 75,8 & 112,8 & 54,2 & 146,5 & 148,8 & 77,5 & 109,1 & 85,3 & 523,9 & 379,0 & 859,5 & 11,3 \\
\hline Kharkiv & 71,7 & 87,6 & 99,1 & 127,6 & 140,1 & 223,9 & 167,1 & 169,0 & 121,0 & 413,2 & 545,5 & 7,6 \\
\hline Kherson & 39,9 & 55,4 & 56,0 & 34,0 & 39,1 & 26,4 & 4,1 & 90,5 & 149,6 & 57,8 & 133,7 & 3,4 \\
\hline Khmelnytskyi & 166,4 & 208,6 & 180,3 & 261,5 & 281,6 & 139,2 & 61,3 & 52,4 & 122,0 & 171,0 & 726,2 & 4,4 \\
\hline Cherkasy & 83,5 & 86,3 & 78,6 & 106,1 & 103,6 & 125,8 & 64,7 & 79,8 & 242,5 & 569,1 & 527,4 & 6,3 \\
\hline Chernivtsi & 273,2 & 219,4 & 206,6 & 320,6 & 348,3 & 454,3 & 462,8 & 531,5 & 817,9 & 982,5 & 1528,1 & 5,6 \\
\hline Chernihiv & 132,2 & 175,4 & 225,2 & 272,1 & 223,7 & 141,0 & 129,9 & 145,9 & 346,6 & 547,4 & 525,5 & 4,0 \\
\hline Kyiv (city) & 69,7 & 301,2 & 273,0 & 79,3 & 405,8 & 42,2 & 54,1 & 122,8 & 105,1 & 127,2 & 146,6 & 2,1 \\
\hline Sevastopol (city) & 35,8 & 32,1 & 121,5 & 131,0 & 41,9 & $\ldots$ & $\ldots$ & $\ldots$ & $\ldots$ & $\ldots$ & $\ldots$ & $\mathrm{x}$ \\
\hline
\end{tabular}

Notes: * according to the methodology of the State Statistics Service of Ukraine, the investment expenditures of households include the following items of non-consumer expenditures: purchase of shares, real estate, construction, overhaul, bank deposits.

"..." - no data.

Source: compiled by the authors according to the data (Derzhavna sluzhba statystyky Ukrainy. Vytraty $i$ resursy domohospodarstv Ukrainy, 2009, 2019)

development. Therefore, the empirical indicator can be the gross regional product (GRP) to analyze the latter. Experts have determined that the economic growth of a country or region directly depends on investment, a sufficient amount of which is at least $27-35 \%$ of GDP or GRP. However, for a long time, gross savings in Ukraine (from the population, enterprises, and the state) do not exceed $15 \%$ of GDP. Thus, more than $60 \%$ of gross savings are provided by non-financial corporations and households - only $20 \%$, while the proportion is reversed in developed countries (Kraina proidannia, 2019).

There are no comprehensive regional statistics on organized and unorganized household savings, except for some surveys conducted by the statistical system. Therefore, the size and dynamics of potential savings can be estimated by deducting the accumulated capital of households not used in the current year after making all (consumer and non-consumer) expenditures. In essence, this is the difference between total resources and total household expenditures. The saved resources can potentially be used to invest in future income or become a financial "cushion" to protect the population from economic crises and shocks (Table 3). It is important to note that the savings capacity, as the total capacity of households to accumulate resources, during 20092019 increased in Ukraine 9.4 times: the most - in Ivano-Frankivsk region (20.5 times), the least - in Kirovograd, Chernivtsi, and Zaporizhia regions (3 times). However, the dynamics of the indicator during the analyzed period were unstable, which is evidence of the influence of various factors on these processes, including macroeconomic crises, imbalances in regional labor markets, the spread of the shadow economy, and informal employment.

According to Figure 3, most oblasts of Ukraine in 2019 showed a lower level of accumulated total 
Vol. 2 No. 3, 2021

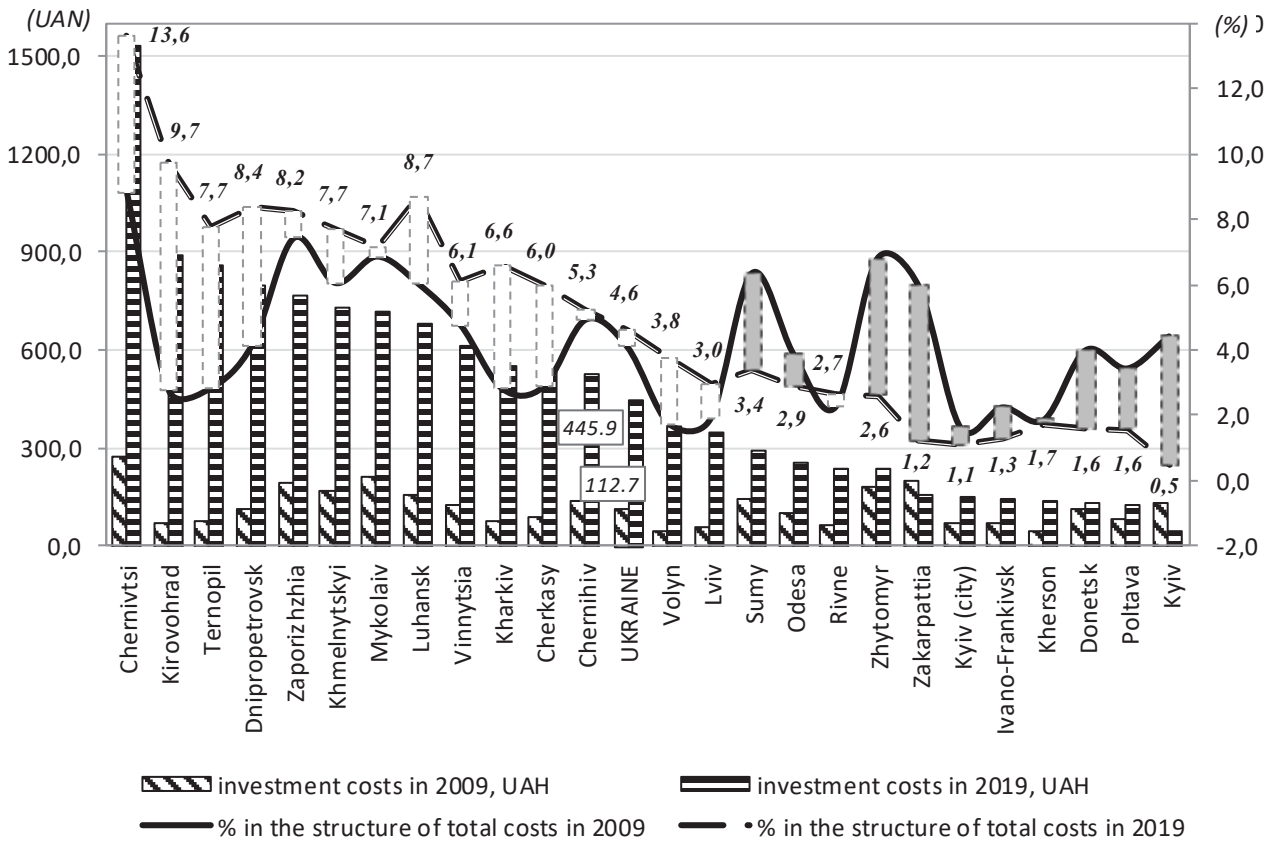

Figure 2. Distribution of investment expenditures of households by regions of Ukraine and their share in the structure of total spending, 2009 and 2019 (on average per month per household)

Source: compiled by the authors according to the data (Derzhavna sluzhba statystyky Ukrainy. Vytraty $i$ resursy domohospodarstv Ukrainy, 2009, 2019)

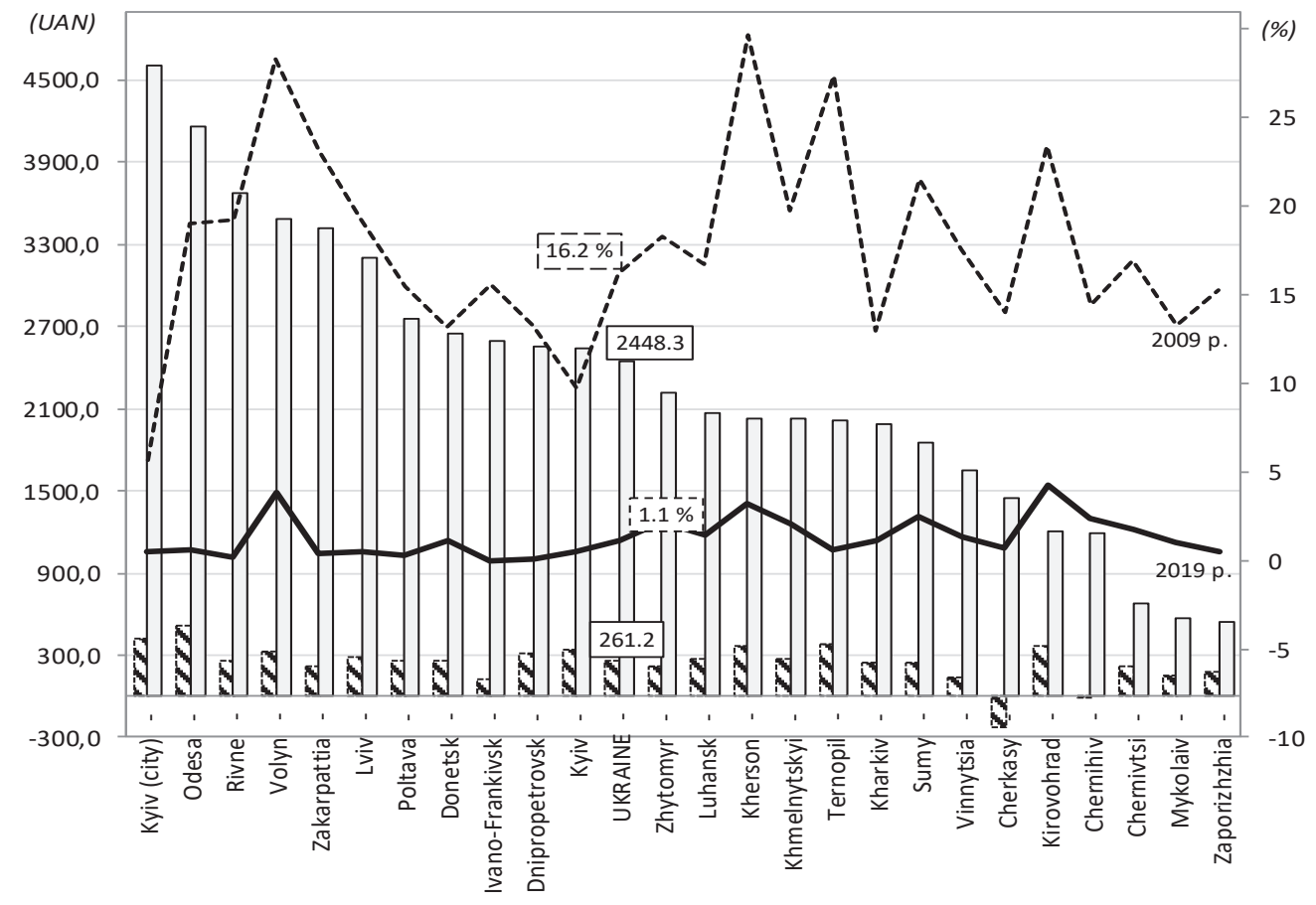

XXaccumulated total resources in 2009, UAH

$\square$ accumulated total resources in 2019, UAH

--..\% of poor hous eholds (2009)

$\%$ of poor hous eholds (2019)

Figure 3. The amount of accumulated total resources of households * and the share of low-income families with real incomes below the statutory subsistence level, by regions of Ukraine, 2009, 2019

Note: * saved (unused) resources that could potentially be used to invest in future income. Calculated as the difference between total resources and total household expenditures (average per month per household).

Source: compiled by the authors according to the data (Derzhavna sluzhba statystyky Ukrainy. Vytraty $i$ resursy domohospodarstv Ukrainy, 2009, 2019) 
Table 3

Accumulated total resources of households * by regions of Ukraine

(on average per month per household, UAH), 2009-2019

\begin{tabular}{|c|c|c|c|c|c|c|c|c|c|c|c|c|}
\hline & 2009 & 2010 & 2011 & 2012 & 2013 & 2014 & 2015 & 2016 & 2017 & 2018 & 2019 & $2019 / 2009$ \\
\hline UKRAINE & 261,2 & 396,4 & 385,7 & 542,5 & 640,3 & 514,4 & 279,7 & 518,4 & 1025,8 & 1595,5 & 2448,3 & 9,4 \\
\hline $\begin{array}{l}\text { Autonomous } \\
\text { Republic of Crimea }\end{array}$ & 330,9 & 265,0 & 291,8 & 404,5 & 412,2 & $\cdots$ & $\cdots$ & $\cdots$ & $\cdots$ & $\cdots$ & $\cdots$ & $\mathrm{x}$ \\
\hline Vinnytsia & 133,6 & 130,1 & 68,4 & 122,2 & 408,9 & 331,8 & 575,8 & 471,9 & 591,3 & 1254,1 & 1647,8 & 12,3 \\
\hline Volyn & 332,2 & 367,2 & 343,5 & 674,8 & 694,4 & 443,4 & 66,9 & 585,0 & 1456,0 & 1806,4 & 3481,7 & 10,5 \\
\hline Dnipropetrovsk & 319,0 & 508,7 & 416,4 & 612,3 & 749,6 & 543,5 & 478,3 & 374,4 & 814,6 & 1124,2 & 2554,5 & 8,0 \\
\hline Donetsk & 255,8 & 628,8 & 661,5 & 1017,6 & 1023,5 & 349,2 & 367,5 & 320,4 & 1027,8 & 1824,0 & 2648,3 & 10,4 \\
\hline Zhytomyr & 222,9 & 195,5 & 397,5 & 253,0 & 521,6 & 425,6 & 28,9 & 432,7 & 700,9 & 1540,8 & 2216,2 & 9,9 \\
\hline Zakarpattia & 220,5 & 287,0 & 269,6 & 559,5 & 414,0 & 320,7 & 227,5 & 221,2 & 1110,0 & 1013,3 & 3413,3 & 15,5 \\
\hline Zaporizhzhia & 180,5 & 255,7 & 216,7 & 262,8 & 288,1 & 209,0 & 228,4 & 399,3 & 403,0 & 454,2 & 546,1 & 3,0 \\
\hline Ivano-Frankivsk & 126,4 & 174,5 & 213,6 & 319,8 & 405,0 & 419,6 & 426,6 & 394,4 & 1310,1 & 1661,6 & 2587,2 & 20,5 \\
\hline Kyiv & 337,2 & 461,6 & 487,0 & 764,9 & 661,1 & 1042,7 & 885,8 & 994,8 & 1541,0 & 1944,9 & 2535,0 & 7,5 \\
\hline Kirovohrad & 366,8 & 392,5 & 568,9 & 651,1 & 570,5 & 448,4 & 51,4 & 582,4 & 944,5 & 1542,6 & 1208,1 & 3,3 \\
\hline Luhansk & 272,6 & 336,6 & 521,2 & 537,1 & 934,8 & 405,8 & 626,7 & 881,0 & 1173,3 & 1460,5 & 2069,2 & 7,6 \\
\hline Lviv & 278,9 & 320,2 & 416,8 & 602,7 & 604,9 & 601,4 & $-54,9$ & 397,5 & 1172,1 & 1860,7 & 3202,5 & 11,5 \\
\hline Mykolaiv & 154,9 & 164,9 & 71,3 & 136,6 & 164,8 & 206,9 & 160,5 & 284,0 & 551,9 & 564,4 & 576,3 & 3,7 \\
\hline Odesa & 520,6 & 591,7 & 445,8 & 1006,4 & 1142,3 & 1115,4 & 502,2 & 1306,7 & 2146,9 & 3378,3 & 4163,3 & 8,0 \\
\hline Poltava & 263,4 & 645,1 & 283,7 & 551,2 & 631,9 & 705,8 & 190,4 & 771,6 & 1235,5 & 2536,7 & 2752,4 & 10,5 \\
\hline Rivne & 260,3 & 488,0 & 354,1 & 594,8 & 781,6 & 773,2 & 562,8 & 1255,5 & 1812,6 & 2818,3 & 3669,7 & 14,1 \\
\hline Sumy & 241,0 & 298,9 & 312,4 & 546,2 & 553,6 & 352,9 & 205,0 & 504,1 & 612,7 & 976,2 & 1856,4 & 7,7 \\
\hline Ternopil & 380,4 & 222,9 & 417,7 & 280,3 & 577,1 & 293,3 & $-87,8$ & 470,3 & 777,2 & 1666,8 & 2007,2 & 5,3 \\
\hline Kharkiv & 250,5 & 374,7 & 339,5 & 445,0 & 515,7 & 471,3 & 357,0 & 354,8 & 726,7 & 1110,6 & 1982,5 & 7,9 \\
\hline Kherson & 361,6 & 346,1 & 89,9 & 263,7 & 282,7 & 403,7 & 348,8 & 609,7 & 1059,9 & 1537,5 & 2033,1 & 5,6 \\
\hline Khmelnytskyi & 265,8 & 299,6 & 375,5 & 519,0 & 524,4 & 652,9 & 415,5 & 600,0 & 1185,8 & 1722,2 & 2032,2 & 7,6 \\
\hline Cherkasy & $-225,3$ & $-124,4$ & $-156,8$ & $-109,0$ & 66,7 & 84,7 & $-359,3$ & $-27,9$ & 908,0 & 355,1 & 1450,4 & $\mathrm{x}$ \\
\hline Chernivtsi & 217,2 & 329,4 & 286,5 & 421,6 & 468,7 & 400,9 & 103,2 & 113,8 & 152,4 & 573,6 & 678,9 & 3,1 \\
\hline Chernihiv & $-7,9$ & 84,9 & $-75,0$ & 264,7 & 205,9 & 329,1 & 25,0 & 161,4 & 440,2 & 578,5 & 1184,3 & $\mathrm{x}$ \\
\hline Kyiv (city) & 422,0 & 995,3 & 1051,4 & 805,4 & 1062,0 & 671,9 & 83,4 & 503,1 & 1280,5 & 2687,7 & 4609,2 & 10,9 \\
\hline Sevastopol (city) & $-23,5$ & $-243,6$ & $-325,0$ & 110,8 & 690,5 & $\ldots$ & $\ldots$ & $\ldots$ & $\ldots$ & $\ldots$ & $\ldots$ & $\mathrm{x}$ \\
\hline
\end{tabular}

Notes: ${ }^{*}$ saved (unused) resources that could potentially be used to invest in future income. Calculated as the difference between total resources and total household expenditures.

"..." - no data.

Source: compiled by the authors according to the data (Derzhavna sluzhba statystyky Ukrainy. Vytraty i resursy domohospodarstv Ukrainy, 2009, 2019)

resources of households relative to the national indicator (UAH 2,448.3 on average per household per month).

At the same time, almost all regions of this majority (except for Ternopil, Cherkasy, Mykolaiv, and Zaporizhia oblasts) were characterized by a higher level of household poverty according to the income criterion compared to the national average (1.1\%). Accordingly, in those regions where households tended to accumulate more resources, the percentage of lowincome families mainly was lower than in Ukraine as a whole.

Based on the analysis of different models of household behavior in 2009-2019, the structure of their general activity (consumer, investment, and savings) was compiled, which allowed to find out the financial orientations of households by region. Listed in Figure 4, the decomposition of the financial capacity of households in 2019 shows that most of them focus on consumer behavior (i.e., do not have the opportunity to allocate a significant portion of income to savings) with a share of consumer spending from $64.2 \%$ to $84.0 \%$, with a predominance of values higher than the national level $(72.8 \%)$. The investment costs also vary region - from $0.4 \%$ to $12.8 \%$, and the share of unused resources into savings ranged from $5.5 \%$ to $32.3 \%$.

Given that there is no empirically proven optimal level of investment costs and optimal savings, we should focus on increasing the shift of emphasis in the direction of organized saving behavior and the transformation of accumulated capital into investment resources. Thus, the leading role in these processes is played by the credit and banking system. However, recent structural reforms in Ukraine's banking sector have harmed household deposits' protection and confidence 
in financial institutions. The low level of financial literacy of citizens, who are more prone to disorganized saving behavior in accumulating cash without placing it in the relevant financial institutions, also contributes. However, the natural source of domestic investment in the national economy is primarily organized household savings. The latter's growth is evidence of improving the welfare of the population and strengthening confidence in financial institutions and the state in general.

Unfortunately, there are few reasons for increasing the savings activity of the population in Ukraine, as wages predominate in the structure of total household resources. As you know, it is an indicator that determines the overall standard of living and savings and investment behavior of households. In Ukraine, the average monthly salary at the beginning of 2020 was 397 EUR, while in Poland, the value of this indicator was 1114 EUR, in Romania - 742 EUR, in the Czech Republic - 1250 EUR, in Germany 3260 EUR (Labour Market (incl. LFS) hus, Ukraine lags behind the EU countries (including the poorest) several times the average wage.

Moreover, the deteriorating economic situation in the country and regions, and, consequently, the reduction of guarantees of stable employment and a decent standard of living of households push citizens to try to find a job with higher wages, to get an education in other countries. Accordingly, with declining incomes, active inflation, exceeding the growth rate of household expenditures over income growth rates, limited opportunities for citizens to save and invest due to high food expenditures, migration sentiment is growing. These sentiments change especially sharply during periods of crisis and revolutionary change, as confirmed by a recent study by the authors (Levytska, Mulska, 2020).Critical periods in the economic and political life of Ukraine (the Orange Revolution,

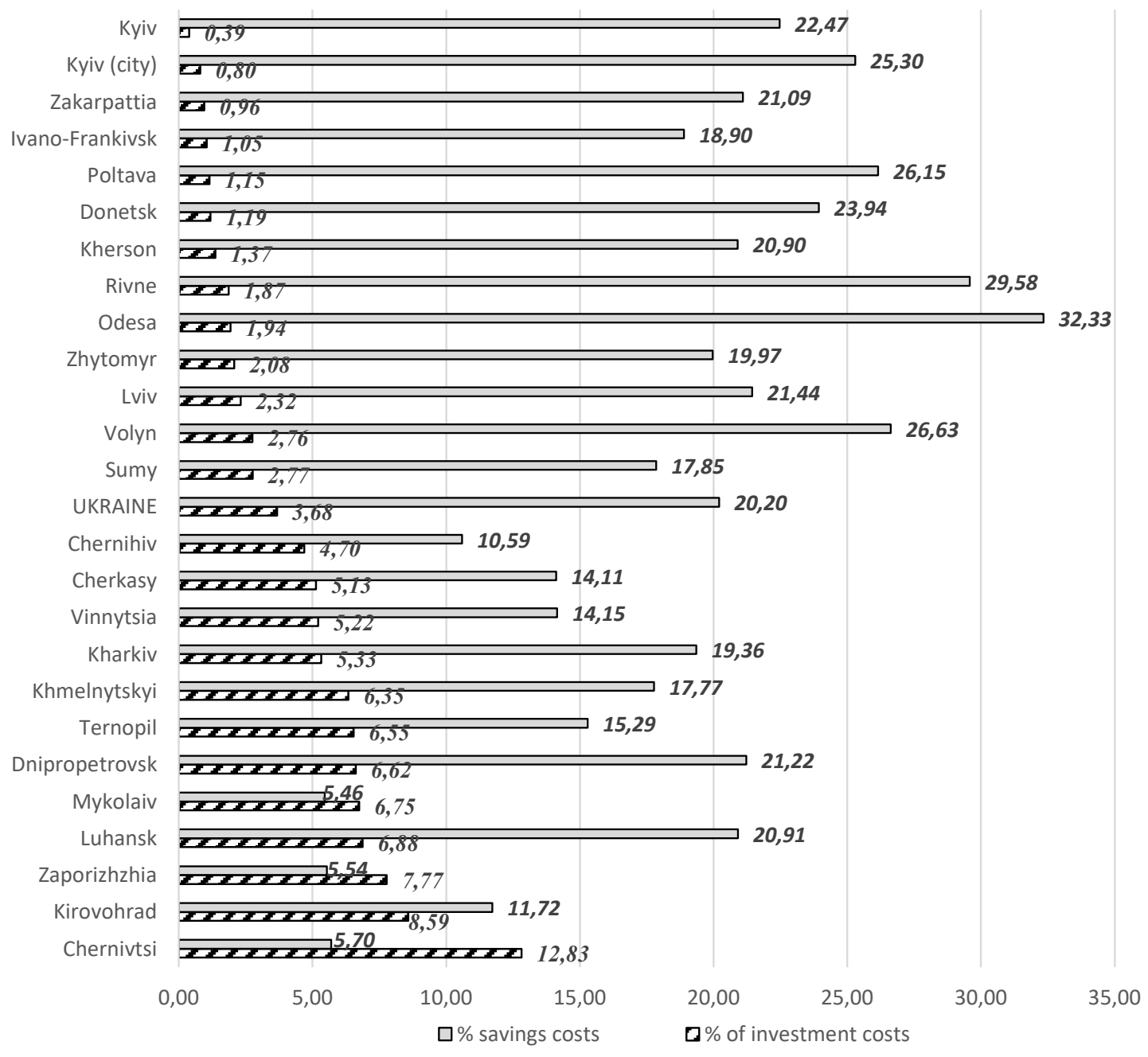

a) investment and savings behavior of households

Figure 4. Decomposition of financial capacity of Ukrainian households: regional section, 2019

Source: compiled by the authors according to the data (Derzhavna sluzhba statystyky Ukrainy. Vytraty i resursy domohospodarstv Ukrainy, 2009, 2019) 


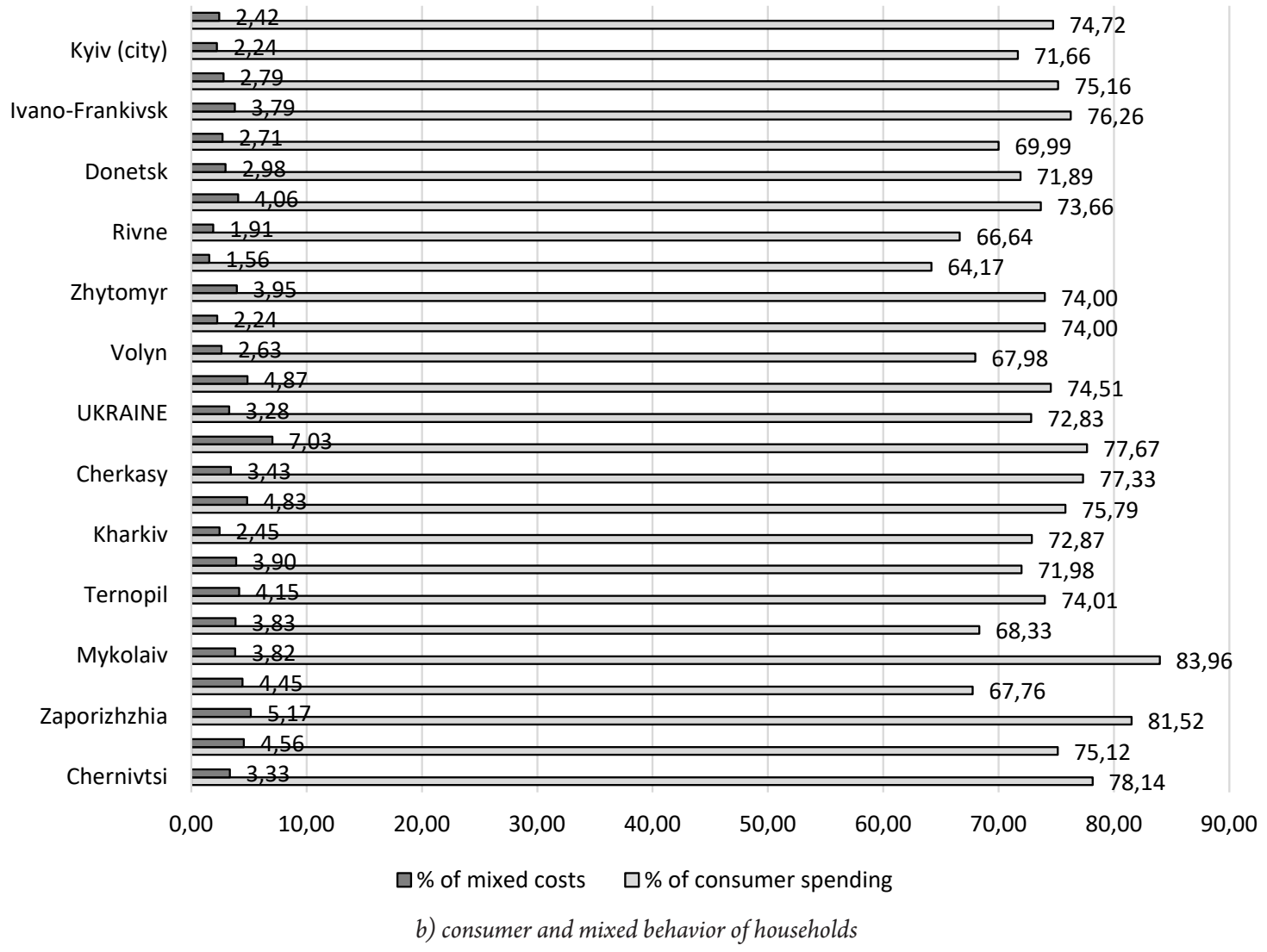

Figure 4. Decomposition of financial capacity of Ukrainian households: regional section, 2019

Source: compiled by the authors according to the data (Derzhavna sluzhba statystyky Ukrainy. Vytraty i resursy domohospodarstv Ukrainy, 2009, 2019)

the Great Recession of 2008-2009, and the Dignity Revolution) significantly affected the trends of external migration of the population of Ukraine and border regions, increasing disparities in regional labor markets and reducing the financial stability of households.

\section{Conclusions}

The financial potential of households, expressed in terms of cash and non-cash income, affects the formation of a model of their economic behavior and natural and potential consumer capacity. At the same time, savings activity is determined mainly by the level of total household income and, accordingly, the share of resources accumulated after implementing all expenditures. However, not all household savings are converted into investment resources, so the
Ukrainian economy is experiencing acute shortages. It was found that the average monthly volume of investments made by households in Ukraine through the purchase of shares, real estate (houses, apartments, cottages, garages), construction, overhaul, bank deposits, as well as contributions to private pension funds in 2019. was only $3.7 \%$ in the structure of total household resources. Thus, this indicates the need to shift the emphasis in consumer behavior to strengthen the role of non-consumer, particular investment, costs. The state must provide favorable institutional conditions to stimulate public investment and maintain the internal socio-economic environment, resistant to various crises and shocks. An essential tool here is an effective regional policy aimed at leveling interregional disparities and forming effective long-term strategies for the financial behavior of households with full use of its investment potential.

\section{References:}

Bil, M. M., \& Mulska, O. P. (2021). Modeli spozhyvchoi povedinky domohospodarstv ta rehionalni osoblyvosti yikh formuvannia v Ukraini [Models of consumer behavior of households and regional features of their formation in Ukraine]. Regional economy, 2.

Cherenko, L. M. (2019). Kompleksna otsinka bidnosti ta sotsialnoho vidchuzhennia v Ukraini za 2016-2018 roky: analitychna zapyska [Comprehensive assessment of poverty and social exclusion in Ukraine for 2016-2018: an analytical note]. MV Institute of Demography and Social Research Birds of the National Academy of Sciences of Ukraine. 
Derkach, T. V. (2020). Uzahalnena kupivelna povedinka spozhyvachiv torhivelnykh posluh [The generalized purchasing behavior of consumers of trade services]. Market economy: modern theory and practice of management, 2(45), 19. DOI: https://doi.org/10.18524/2413-9998/2020.2(45).201420

Derzhavna sluzhba statystyky Ukrainy. Sotsialno-ekonomichne stanovyshche domohospodarstv Ukrainy u 2019 rotsi (za danymy vybirkovoho obstezhennia umov zhyttia domohospodarstv) [Socio-economic situation of households in Ukraine in 2019 (according to a sample survey of living conditions of families)]. Available at: http://www.ukrstat.gov.ua/druk/publicat/kat_u/publdomogosp_u.htm

Derzhavna sluzhba statystyky Ukrainy. Vytraty i resursy domohospodarstv Ukrainy (za 2009, 2019 rr.) [Expenditures and resources of households in Ukraine (for 2009, 2019)]. Available at: http:/ /www.ukrstat.gov.ua/ druk/publicat/kat_u/publdomogosp_u.htm

Harasymiv, T. (2016). Povedinka liudyny: filosofsko-pravova refleksiia «diialnist» ta «aktyvnist»[Human behavior: philosophical and legal reflection "activity" and "activity"]. Bulletin of the National University "Lviv Polytechnic". Series: Legal Sciences, 855, 147-151.

Kraina proidannia. Chomu vlada ne stymuliuie Ukraintsiv zaoshchadzhuvaty? Economic truth. Available at: https:/ /www.epravda.com.ua/publications/2019/08/26/650910

Kuzmuk, O. M. (2015). Spozhyvatska povedinka yak mekhanizm identychnosti [Consumer behavior as a mechanism of identity]. Faces, 4, 12-16.

Labour Market (incl. LFS). Earnings / Eurostat. Available at: https://ec.europa.eu/eurostat/web/labour-market/ earnings

Levytska, O. O., \& Mulska, O. P. (2020). Modeliuvannia intensyvnosti zovnishnoi mihratsii naselennia Ukrainy $\mathrm{v}$ umovakh posylennia seredovyshcha vyshtovkhuvannia [Modeling of intensity of external migration of the population of Ukraine in the conditions of strengthening of the ejection environment]. Ukraine economy, 9, 48-65. Available at: https://doi.org/10.15407/economyukr.2020.09.048

Melykh, O. Yu. (2020). Zaoshchadzhennia domohospodarstv: sotsialno-ekonomichna rol ta tendentsii formuvannia v Ukraini [Household savings: socio-economic role and trends in Ukraine]. Efficient economy, 11. DOI: https://doi.org/10.32702/2307-2105-2020.11.67

Mulska, O. P. (2021). Kontseptualna sutnist zviazku ekonomichnoi povedinky domohospodarstv i rozvytku terytorii [The conceptual essence of the connection between economic behavior of households and territorial development]. Economy and society, 24. DOI: https://doi.org/10.32782/2524-0072/2021-24-16

Pohorila, L. M. (2006). Ekonomichnyi zmist ta sutnist vidnosyn spozhyvannia [Economic content and essence of consumption relations]. Formation of a market economy, 16, 28-37.

Stankevych, Yu. Yu. (2008). Sutnist ta kharakterni rysy suchasnoho domohospodarstva [The essence and characteristics of the modern household]. Formation of a market economy, 19, 40-46.

Teremtsova, N. V. (2010). The nature of lawful human behavior (culture of human behavior, the mechanism of individual behavior, anti-social behavior, conformist behavior...) [Pryroda pravomirnoi povedinky liudyny (kultura povedinky liudyny, mekhanizm indyvidualnoi povedinky, antysuspilna povedinka, konformistska povedinka...) ]. Bulletin of NTUU "KPI". Politology. Sociology. Right, 2(6), 167-170.

Vasylkevych, L. O. (2011). Struktura povedinky spozhyvachiv i kharakterystyka yii osnovnykh komponentiv $\mathrm{u}$ systemi ekonomichnykh vidnosyn [The structure of consumer behavior and the characteristics of its main components in the system of economical relations]. Economy and region, 4, 187-191. 